\title{
ESTIMATING FLOW AND RECHARGE RATES OF GROUNDWATER IN WESTERN TAIWAN USING RADIOCARBON AND TRITIUM
}

\author{
TSUNG-KWEI LIU \\ Department of Geology, National Taiwan University, 245 Choushan Road, Taipei 10770 Taiwan
Republic of China
}

\begin{abstract}
The Choushuichi alluvial-fan delta is the largest groundwater system in Taiwan. The coastal area of this fan delta has recently suffered severe land subsidence and sea-water intrusion due to overpumping of groundwater. To study the hydrogeological character of proper water-resource management, an intensive program of geological and water monitoring through well drilling and sampling has been undertaken. At present, radiocarbon dating and/or tritium analysis for samples from $>70$ boreholes has been completed. The clearly defined position of "bomb-tritium front" allows the groundwater flow The flow velocities of the confined aquifer have also accelerated remarkably due to much pumping during the last decades.
.
\end{abstract}

\section{INTRODUCTION}

Two-thirds of Taiwan Island are high (up to $~ 4000$-m elevation) mountainous areas composed of pre-Quaternary indurated to metamorphozed rocks. Economic activities of the island occur mainly on the surrounding coastal alluvial plains and tablelands, where the largest Choushuichi alluvial-fan delta (Fig. 1) in western Taiwan covers $c a .1800 \mathrm{~km}^{2}$. The ground surface slopes westward with a low gradient of 1:400 and is composed of gravel, sand, silt and clay deposited by the Choushuichi stream whose channels shift frequently and radially over the fan delta, which is densely populated and has intensive agricultural cultivation and fish farming. Groundwater demands have sharply increased in recent years, causing environmental problems, especially sea-water intrusion and land subsidence due to over-pumping of groundwater in the coastal areas (Lee and Lin 1992; TWCB 1974). Annual recharge was estimated at $(9-13) \times 10^{8} \mathrm{~m}^{3}$ (Huang 1992), but the present annual pumping has reached $c a .20 \times 10^{8} \mathrm{~m}^{3}$, about twice the amount of recharge. To enable proper planning, development and management of the groundwater resources and better protection of groundwater quality, a program of intensive drilling for sediment cores ( $>50$ boreholes) and construction of water wells ( $>100$ boreholes) has been undertaken during the past $3 \mathrm{yr}$. I discuss here the ages of sediments, hydrogeological framework and flow velocities and recharge rates of groundwater in the fan delta, using ${ }^{14} \mathrm{C}$ dating and bomb-produced tritium tracing.

\section{Tritium Tracing}

"Bomb-tritium" ( ${ }^{3} \mathrm{H}$; half-life $=12.43 \mathrm{yr}$ ) produced by aboveground thermonuclear tests beginning in 1953 has proven to be an excellent tracer in groundwater and oceanic systems (e.g., Brown 1961; Allison and Hughes 1975; Egboka et al. 1983; Broecker and Peng 1982; Robertson and Cherry 1989; Daniels, Fritz and Leap 1991). Before 1953, natural ${ }^{3} \mathrm{H}$ activity in precipitation was estimated at between 4 and 20 tritium units (TU) (Kaufman and Libby 1954; Robertson and Cherry 1989). During the mid-1960s, ${ }^{3} \mathrm{H}$ activity in precipitation rose rapidly to $>3000 \mathrm{TU}$ in the northern hemisphere. Although the absolute ${ }^{3} \mathrm{H}$ activity in precipitation is regionally variable, the location of the mid-1960s "bomb" peak has been used as a reference point for determining long-term groundwater recharge and velocity (e.g., Allison and Hughes 1975; Egboka et al. 1983). In principle, the position of the "leading edge" of the bomb ${ }^{3} \mathrm{H}$ pulse ("bomb tritium front") can provide the same information as the bomb peak. As the last pre-bomb precipitation occurred in 1951, the natural activity of prebomb precipitation in Taiwan area estimated from the present ${ }^{3} \mathrm{H}$ concentration ( 10 TU) (C. J. Chen, personal communication 1994) decayed to $\leq 1 \mathrm{TU}$ in the early 1990s. Thus, the practical rule 


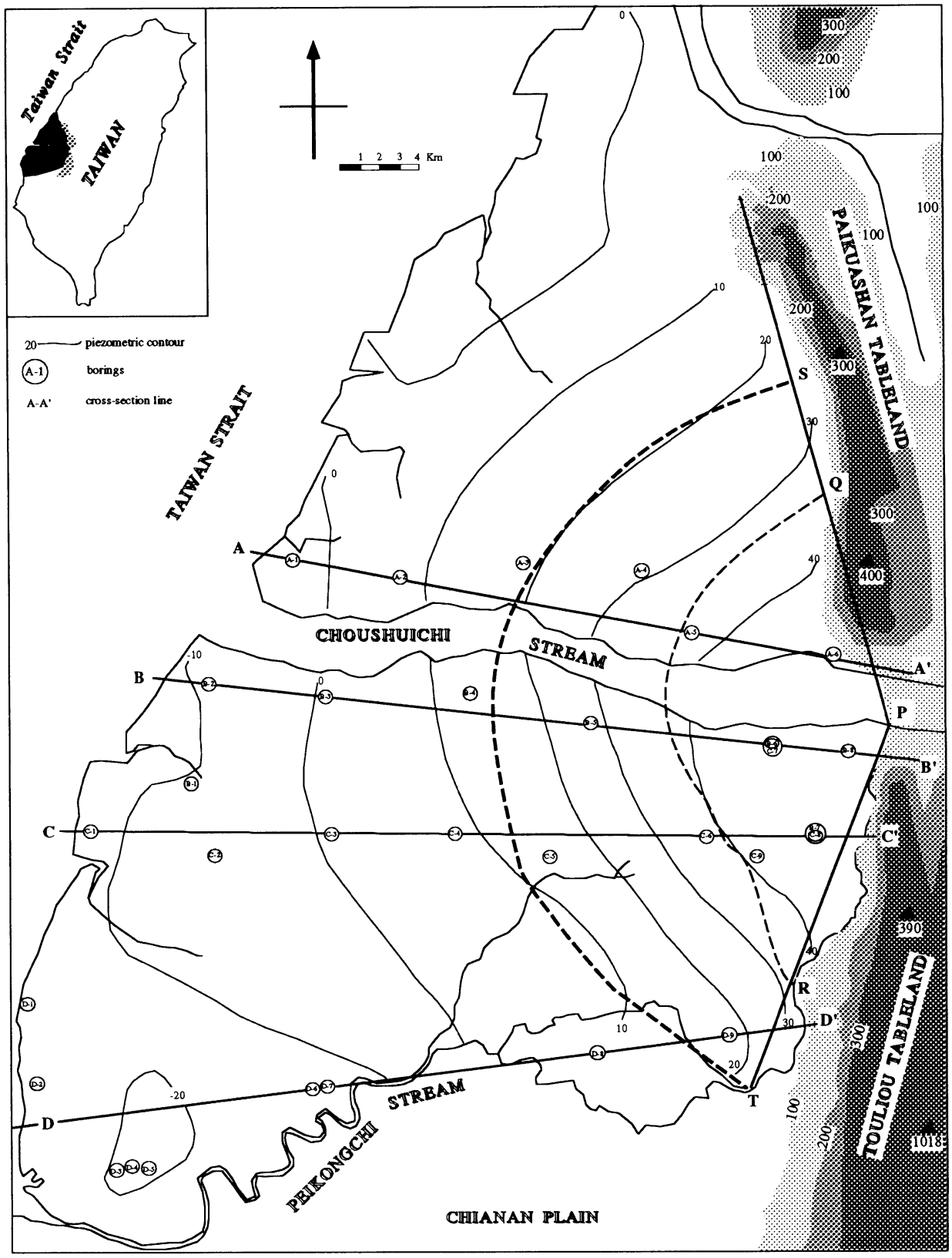

Fig. 1. Map of the study area showing physiographic outlines and regional flow system: $Q---R=$ surface position of the eastern boundary of the Huchi Aquitard; S----T = the position of upward projection of the bombtritium front in the confined aquifer.

in Taiwan for identifying old groundwater ( $>40 \mathrm{yr}$ old) is $\leq 1 \mathrm{TU}$. One assumes that ${ }^{3} \mathrm{H}$ activity $>1$ $\mathrm{TU}$ indicates post-1952 recharge water, and the transition position where the ${ }^{3} \mathrm{H}$ concentration begins to be $>1 \mathrm{TU}$ represents the year AD 1953 ( $\sim 40$ yr old).

\section{Radiocarbon Dating}

Recent depositional ages and stratigraphic correlation of sediments can, in most cases, be determined using radiocarbon $\left({ }^{14} \mathrm{C}\right)$ dating. Along with ${ }^{3} \mathrm{H},{ }^{14} \mathrm{C}$ has also been a useful radionuclide in 
groundwater studies. However, the complexities of geochemistry make groundwater dating difficult. Researchers have developed increasingly sophisticated models to address such geochemical problems as dissolution of ancient carbonates, release of old carbon from the diagenesis of buried organic matter and isotopic fractionation (e.g., Pearson 1965; Wigley, Plummer and Pearson 1978; Ingerson and Pearson 1964; Tamers 1967, 1975; Reardon and Fritz 1978; Deines, Langmuir and Harmon 1974; Mook 1976, 1980; Fontes and Garnier 1979; Parkhurst, Thorstenson and Plummer 1980; Plummer et al. 1990; Cheng 1992). Dispersion is another element making groundwater ages ambiguous except in the theoretical case of a pure piston flow system or of stationary water entrapped in a geological formation. Differences in apparent ages (i.e., relative age) between two sampling points, A and B, aligned along (as nearly as possible) a flow line make it possible to compute the velocity along the direction A to B if dissolved inorganic carbon (DIC) does not react with the aquifer minerals between samples. A value for velocity of groundwater movement was obtained by dividing the distance between sample points by the difference in ${ }^{14} \mathrm{C}$ ages. ${ }^{14} \mathrm{C}$ ages presented in this paper are "conventional ages" as defined by Stuiver and Polach (1977), using $5570 \pm 30 \mathrm{yr}$ as the half-life of ${ }^{14} \mathrm{C}$.

\section{METHODS}

At each study site, one borehole was drilled for taking continuous sediment cores and one or more boreholes were drilled for constructing wells. Each water sample was collected from a single aquifer through the slotted screen of a well casing. I collected two types of water samples: a 45-liter sample for ${ }^{14} \mathrm{C}$ dating, and a 1-liter sample for ${ }^{3} \mathrm{H}$ measurement. The samples were ensured to be fresh and representative by pumping each well long enough to replace the free-standing water in the casing before taking a sample. Dissolved inorganic carbon (DIC) was precipitated in the field. ${ }^{14} \mathrm{C}$ dating of the DIC and tritium analysis were done by the Radiocarbon Laboratory of the National Taiwan University and the Tritium Laboratory of the University of Miami, respectively. Accuracy and precision of ${ }^{3} \mathrm{H}$ measurements are $0.1 \mathrm{TU}$ or better.

The procedures used in this study to precipitate DIC from the water samples for ${ }^{14} \mathrm{C}$ dating are similar to those of Geyh and Wagner (1979) and Hackley, Liu and Coleman (1992). Atmospheric $\mathrm{CO}_{2}$ was prevented from entering the 50-liter carboy during water sampling and precipitation. Two liters of $0.5 \mathrm{M} \mathrm{BaCl}_{2}$ and 2 liters of $0.5 \mathrm{~N} \mathrm{NaOH}$ solutions were added to the water sample through a spigot and mixed thoroughly. After settling, the top solution was drained off through the spigot. The precipitate was then siphoned into a 4-liter vacuum flask and rinsed repeatedly by $\mathrm{CO}_{2}$-free, deionized water. The slurry $\left(\mathrm{BaCO}_{3}\right)$ was converted first to $\mathrm{CO}_{2}$ and finally to benzene in a vacuum system. ${ }^{14} \mathrm{C}$ activity was measured using liquid scintillation counting.

\section{RESULTS AND DISCUSSION}

The Choushuichi-delta has a well-defined fan shape, although its slope gradient is very low. It is bounded on the west by the Taiwan Strait and on the east by the Paikuashan and Touliou tablelands at $c a$. 300-400 m elevation. They are composed of indurated Pleistocene strata with a gently dipping anticline (Wang and Chen 1959), and evidently act as two groundwater divides or eastern boundaries of the groundwater system in the Choushuichi fan delta. On the south, the Choushuichi fan delta merges into the Chianan coastal plain and is tentatively bounded by the Peikongchi stream to the south.

\section{Hydrogeology and Bomb-Tritium Front}

The proximal area of the fan delta is a typical unconfined aquifer composed of gravel and sand $>200$ $\mathrm{m}$ thick. A regional mud/silt layer $c a$. $30 \mathrm{~m}$ thick was found at a depth of $60-30 \mathrm{~m}$ below ground sur- 
face, deposited during the pervasive transgression since the last glacial maximum (Fig. 2). This bed is the most important confining aquitard (named the Huchi aquitard) for the underlying aquifer in the central and distal fan areas. This confined aquifer is the main source of groundwater in the fan delta, especially in the coastal areas where human activity induced sea-water intrusion and land subsidence. Uncorrected ${ }^{14} \mathrm{C}$ data demonstrate that the Huchi aquitard was deposited from ca. 20-6 ka BP when transgression occurred as the eustatic sea level rose since the last glacial maximum. No significant limestone layers were found in the catchment area of the Choushuichi stream or the alluvialfan delta.

Figure 2 shows results of ${ }^{14} \mathrm{C}$ and ${ }^{3} \mathrm{H}$ analyses of water samples collected from 52 wells at 32 sites. The position of "bomb-tritium front" is also shown. The ${ }^{14} \mathrm{C}$ ages generally increase with depth and downgradient. Some ${ }^{14} \mathrm{C}$ ages are anomalous as they are older than the age of either the downgradient or upper water. This may be due to the admixture of ancient entrapped water in or near the clay. In the thick free aquifer of the proximal fan area, the bomb-tritium signal can be clearly observed down to a depth of $>170 \mathrm{~m}$. In the other parts of the fan delta, where the Huchi aquitard occurs, the "bomb" signal was also found throughout the shallow free aquifer above the Huchi aquitard. The "bomb" signal in the confined aquifer reaches as far as 6-10 km downgradient from the eastern edge of the Huchi aquitard, as shown in Figure 1. Site A-1 near the coast is an exception and is the most striking anomaly in respect of the pattern of the tritium front. This may be attributed to the downward leakage of shallow bomb-tritium-containing groundwater along nearby old, inactive wells due to severe overpumping in this area.

The thick unconfined aquifer in the proximal fan is the main and probably the sole natural recharge source for the groundwater of the confined aquifer, as can be inferred from the pattern of the "bombtritium front". Behind the bomb-tritium front, all the ${ }^{3} \mathrm{H}$ and ${ }^{14} \mathrm{C}$ concentrations of the water samples measured to date are less than the minimum post-bomb concentration $(\sim 10 \mathrm{TU}$ and $\sim 110 \mathrm{pMC}$, respectively) of the precipitation in Taiwan. This implies that the newly recharged groundwater is a mixture of modern $(<40 \mathrm{yr})$ bomb-tritium-containing water and much older water.

\section{Flow Velocities and Recharge Rates}

To the west of the "bomb-tritium front", long-term average flow velocities for the confined aquifer below the Huchi aquitard can be estimated by the concepts of relative age and piston flow. Table 1 shows the flow velocities calculated for some segments of the flow lines. Figure 1 shows the locations of the wells. It should be pointed out that no systematic change of the concentration or $\delta^{13} \mathrm{C}$ of the DIC between wells was found (Table 2), implying that the DIC does not react significantly with the aquifer minerals between samples. In estimating the long-range (in $\mathrm{km}$ scale) flow velocity of water in the confined aquifer by the bomb-tritium front, dispersion can be assumed as negligible. In addition, the time needed for the non-piston flow through $c a .60-100 \mathrm{~m}$ thick unconfined aquifer

TABLE 1. Representative Flow Velocities in the Western Part of the Choushuichi Fan Delta

\begin{tabular}{lclrc}
\hline Well site & Distance $(\mathrm{m})$ & \multicolumn{1}{c}{$\begin{array}{c}\text { Age difference } \\
(\mathrm{yr})\end{array}$} & $\begin{array}{c}\text { Flow velocity } \\
\left(\mathrm{m} \mathrm{yr}^{-1}\right)\end{array}$ \\
\hline C-2, C-3 & 6000 & $(6350-4150=)$ & 2200 & 2.7 \\
C-1, C-2 & 6500 & $(16,700-6350=)$ & 10,350 & 0.63 \\
B-2, B-4 & 13,000 & $(7860-5600=)$ & 2260 & 5.8 \\
D-3, D-6 & 13,000 & $(18,000-0750=)$ & 7250 & 1.8 \\
\hline
\end{tabular}




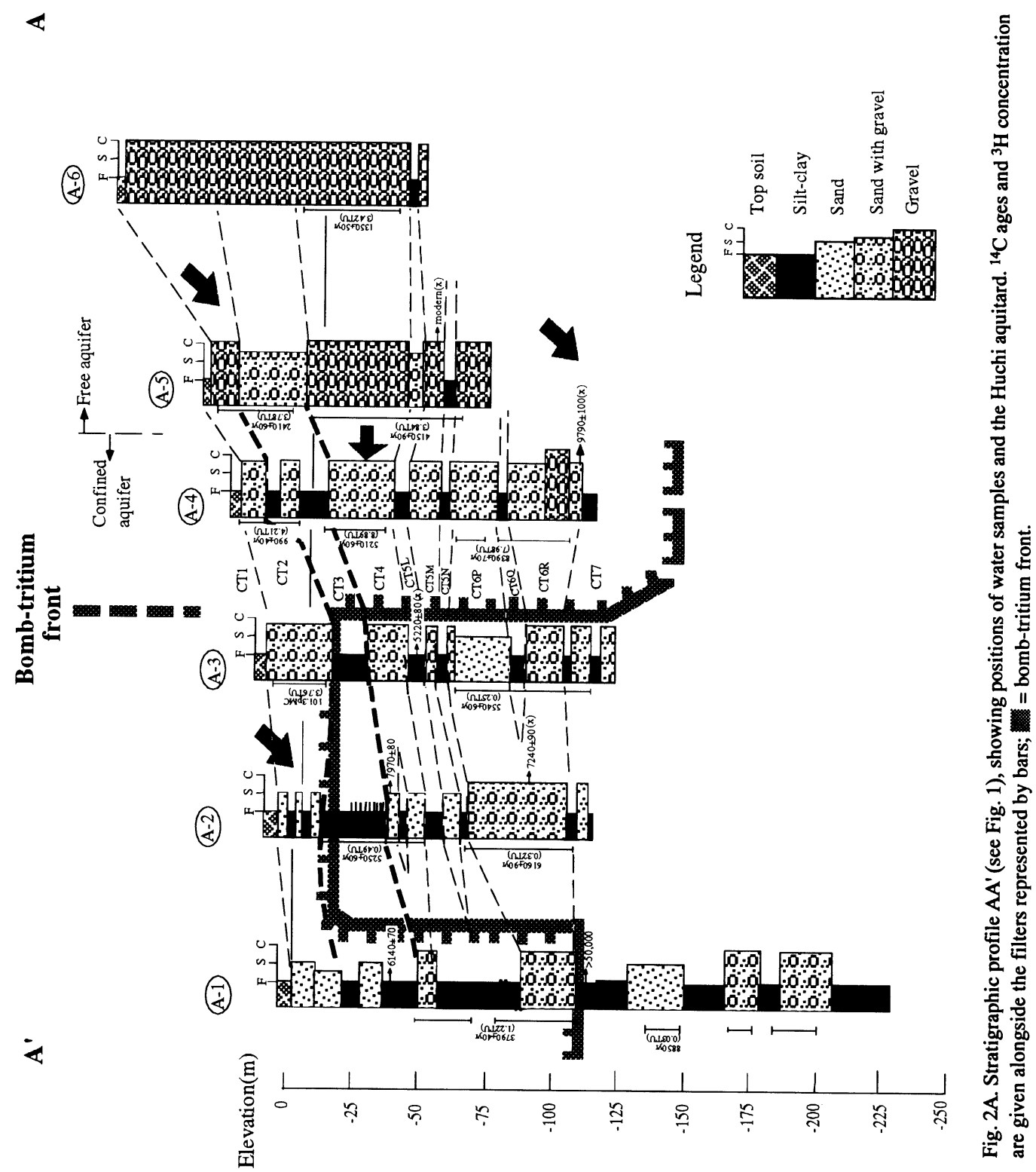




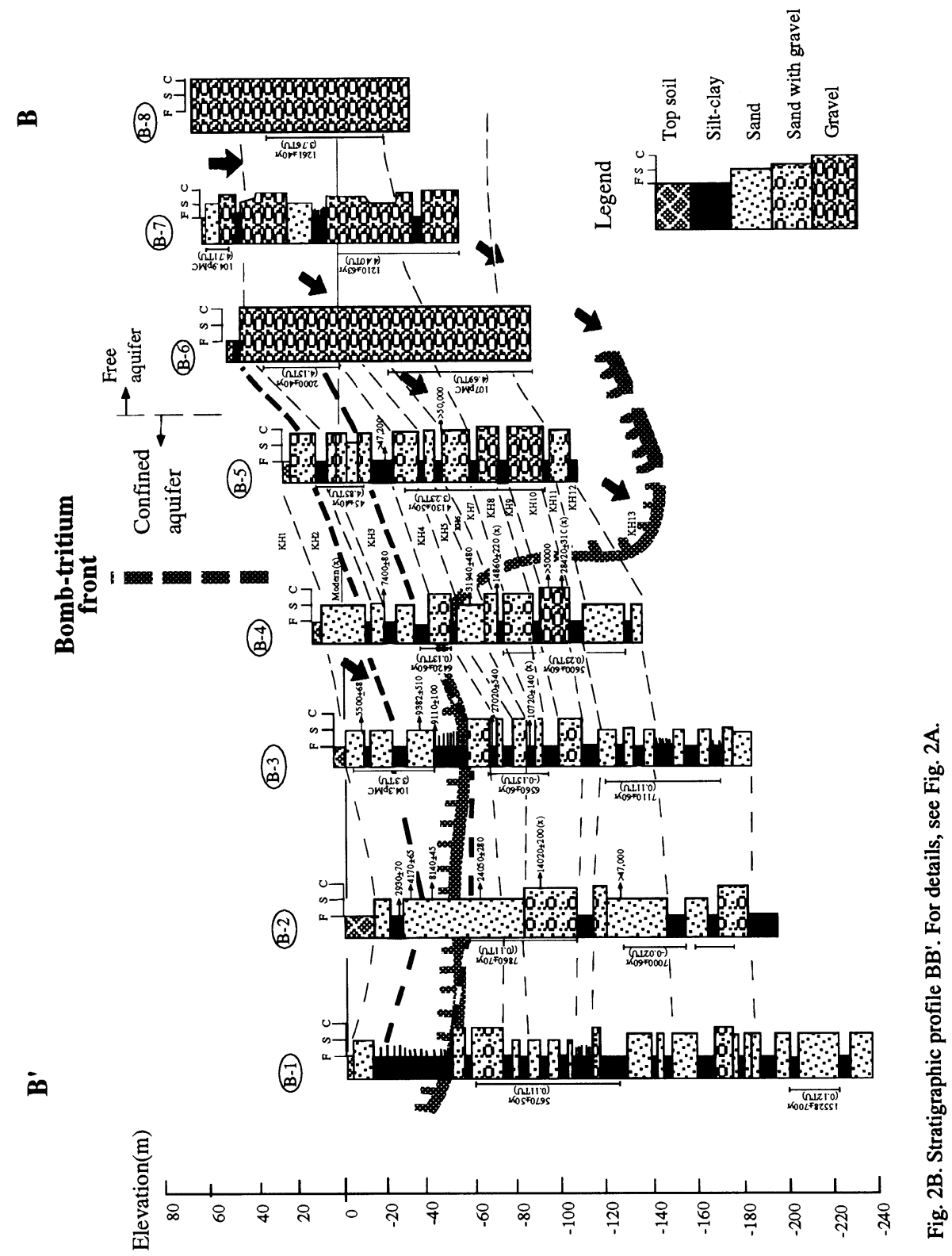




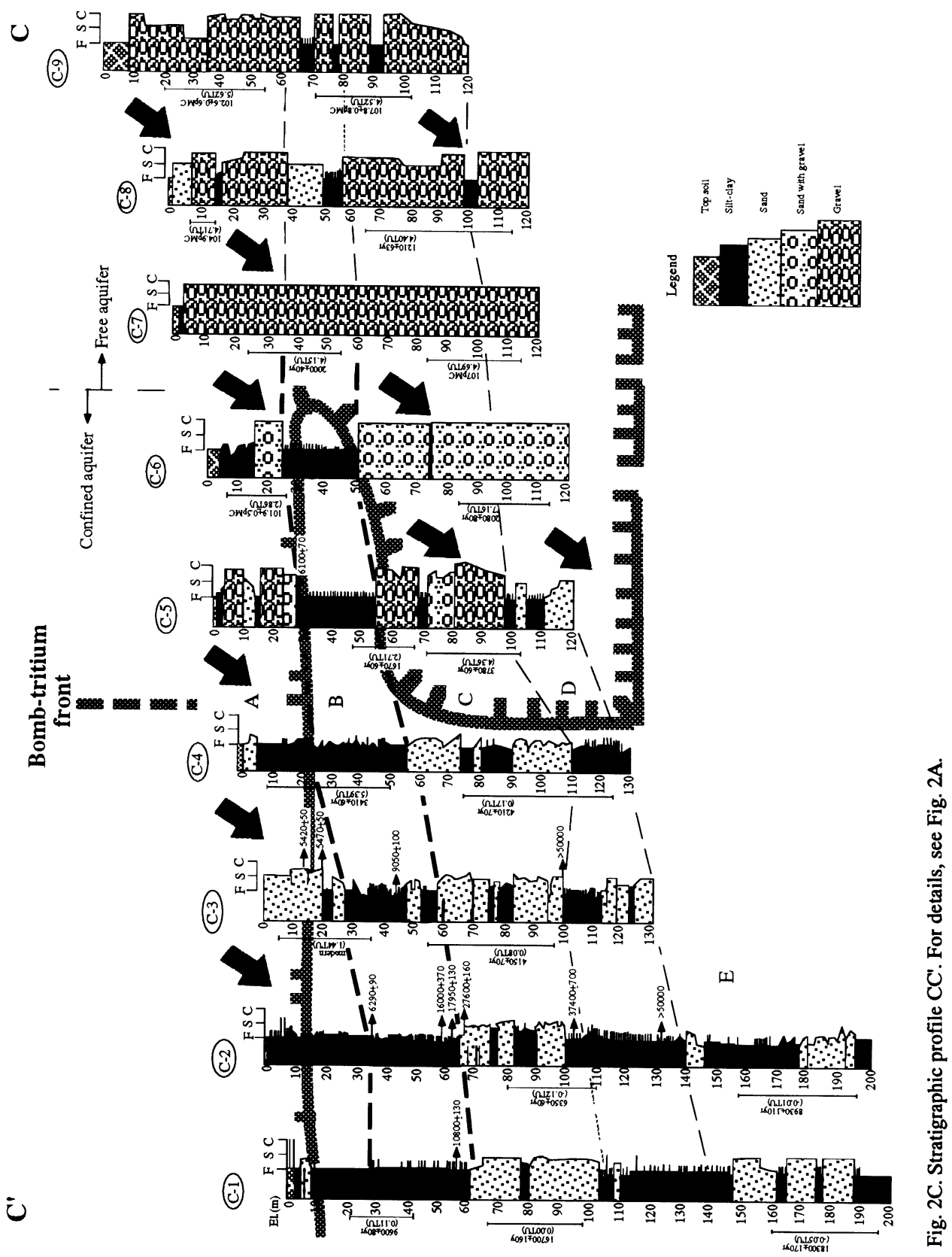




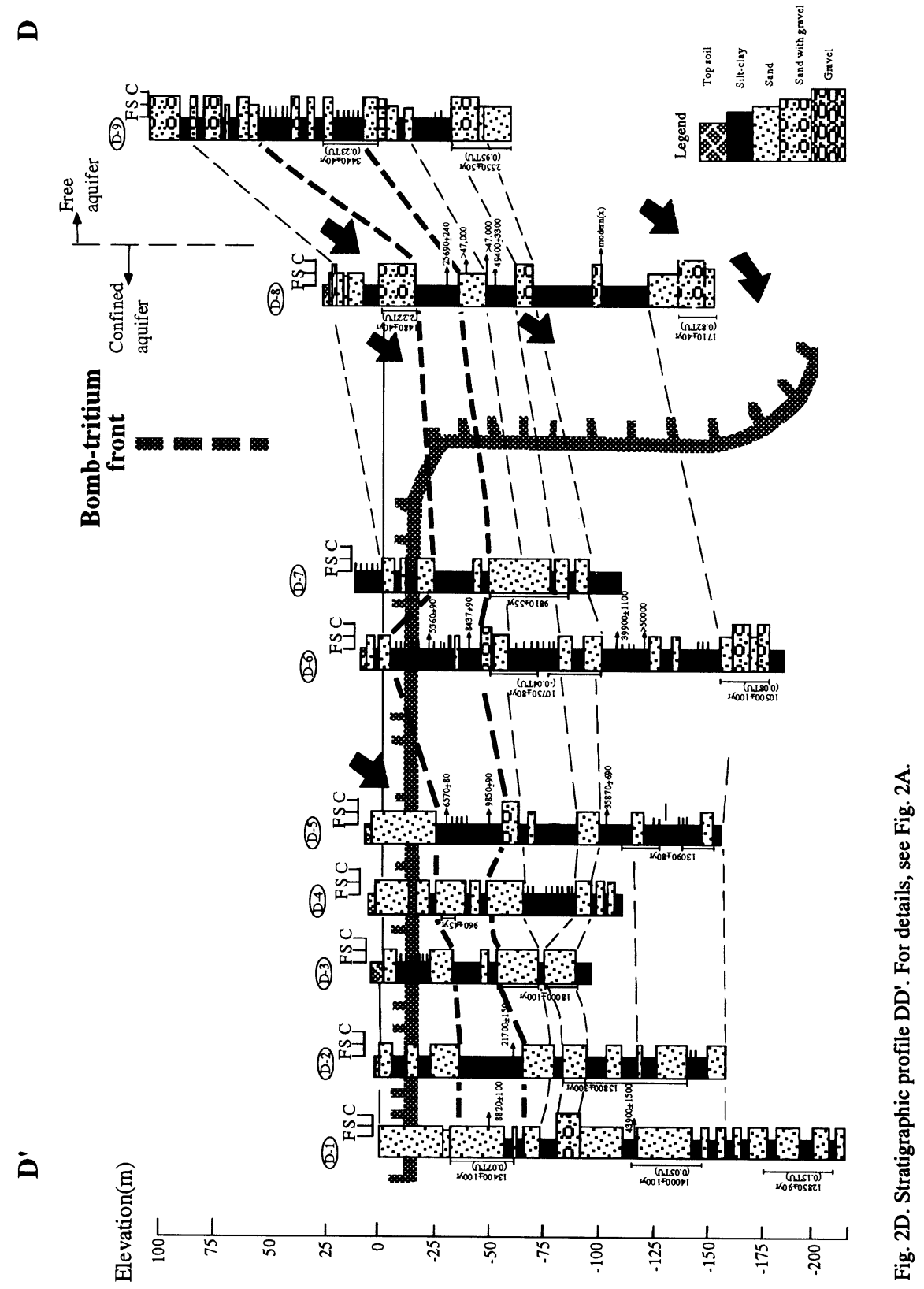


TABLE 2. Concentration and $\delta^{13} \mathrm{C}$ of DIC from

Water Samples

\begin{tabular}{lcc}
\hline $\begin{array}{l}\text { Well site } \\
\text { (DIC }{ }^{14} \mathrm{C} \text { age, BP) }\end{array}$ & $\begin{array}{c}\text { Concentration } \\
(\mathrm{gm} \mathrm{C} / 50 \mathrm{l})\end{array}$ & $\begin{array}{c}\delta^{13} \mathrm{C} \pm \\
0.1(\% 0)\end{array}$ \\
\hline B-2 $(7860)$ & 2.61 & -11.2 \\
B-4 $(5600)$ & 1.89 & -8.2 \\
C-1 $(16,700)$ & 1.89 & -12.1 \\
C-2 $(6350)$ & 2.48 & -8.4 \\
C-3 $(4150)$ & 1.66 & -10.5 \\
D-3 $(18,000)$ & 2.73 & -13.8 \\
D-6 $(10,750)$ & 2.45 & -9.7 \\
\hline
\end{tabular}

before entering the confined aquifer was not taken into account because $60-100 \mathrm{~m}$ is a very short distance compared with the lateral travel distance $(6-10 \mathrm{~km})$ of the bomb-tritium front in the confined aquifer.

Recharge rates are important to groundwater development and management, especially for lowlying, heavily populated areas. From the pattern of the bomb-tritium front (Fig. 1; Fig. 2), the recharge rates of the Choushuichi fan delta can be estimated by a simple model (Fig. 3; Table 3), which uses the relatively impervious Paikuashan and Touliou Tablelands as the northeastern and southeastern boundary of the groundwater system. As stated above, the sole recharge area for the regional confined aquifer is the thick gravels in the proximal part of the fan delta. The line $Q-R$ in Figures 1 and 3 marks the western boundary of this gravelly recharge area. The line $S-T$ is the surface position of upward projection from the bomb-tritium front in the confined aquifer. The bombtritium front represents an interval of $40 \mathrm{yr}$ (1993-1953), and penetrates to a depth of at least $170 \mathrm{~m}$. A reasonable estimate of effective porosity for the fan delta is $30 \%$.

TABLE 3. Estimated Recharge Rates of the Different Parts of the Choushuichi Fan Delta

\begin{tabular}{|c|c|c|c|c|c|c|c|}
\hline \multicolumn{3}{|c|}{$\begin{array}{l}\text { Components of the Fan Delta } \\
\text { (Fig. 3) }\end{array}$} & $\begin{array}{l}\text { Area } \\
\left(\mathrm{km}^{2}\right)\end{array}$ & $\begin{array}{l}\text { Thickness } \\
\text { (m) }\end{array}$ & Porosity & $\begin{array}{c}\text { Total } \\
\text { water } \\
\text { volume } \\
\left(\times 10^{8} \mathrm{~m}^{3}\right)\end{array}$ & $\begin{array}{l}\text { Recharge rate } \\
\left(\times 10^{8} \mathrm{~m}^{3} \mathrm{yr}^{-1}\right)\end{array}$ \\
\hline \multirow[t]{2}{*}{ Proximal fan } & \multirow[t]{2}{*}{ PQR } & PST & 460 & 170 & 0.3 & 235 & \multirow{2}{*}{$\begin{array}{c}(235-17) / 40= \\
5.5\end{array}$} \\
\hline & & $\mathrm{Q}_{1} \mathrm{~S}_{1} \mathrm{~T}_{1} \mathrm{R}_{1}$ & 290 & 20 & 0.3 & 17 & \\
\hline \multirow{2}{*}{$\begin{array}{l}\text { Middle } \\
\text { and } \\
\text { distal fans }\end{array}$} & \multicolumn{2}{|c|}{ QUVR } & 1630 & 24 & 0.3 & 117 & 2.9 \\
\hline & \multicolumn{2}{|c|}{$\begin{array}{l}\text { Discharge through } \\
U_{1} V_{1} \text { profile to } \\
\text { the sea }\end{array}$} & 1.4 & $\begin{array}{c}150 \\
\text { (inferred } \\
\text { velocity) } \\
\end{array}$ & 0.3 & 25 & 0.6 \\
\hline Total fan delta & \multicolumn{2}{|l|}{ PUV } & 1800 & 170 & 0.3 & 360 & 9.0 \\
\hline $\begin{array}{l}\text { Confined } \\
\text { aquifer below } \\
\text { Huchi aquitard }\end{array}$ & \multicolumn{2}{|l|}{ QRST } & 290 & 110 & 0.3 & 96 & 2.4 \\
\hline
\end{tabular}

The saturated zone in the shallow free aquifer of the middle and distal parts of the fan is $c a .24 \mathrm{~m}$ thick. Annual discharge of the shallow aquifer to the sea was calculated using the same flow velocity of $150 \mathrm{~m} \mathrm{yr}^{-1}$ as that of the confined aquifer because of the similarity of their hydrologic character- 


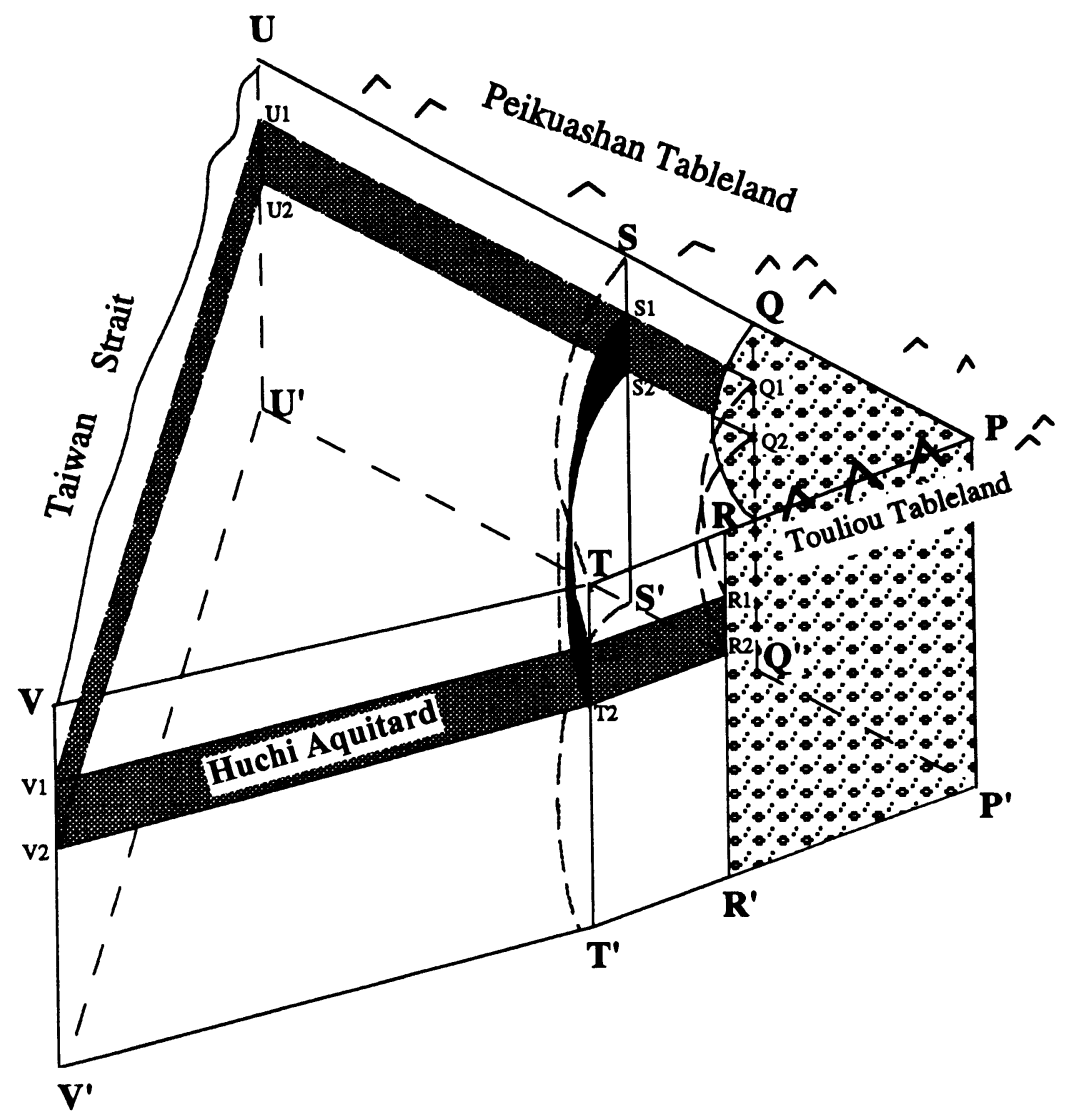

Fig. 3. Scheme of the hydrogeological framework of the Choushuichi fan delta. The gently folded and indurated Peikuashan and Touliou Tablelands act as the eastern boundary of the groundwater system. The surface position of upward projection of the eastern boundary of the regional Huchi Aquitard and the bomb-tritium front of the confined aquifer below the Huchi Aquitard are indicated by the lines QR and ST, respectively.

istics. The total recharge rate obtained is $9.0 \times 10^{8} \mathrm{~m}^{3} \mathrm{yr}^{-1}$, which agrees well with the value estimated by water budget analysis (GWIT 1957).

Representative values of permeability for fine and medium sand cover a range from $\left(2 \times 10^{-7}-2 \times\right.$ $\left.10^{-4}\right) \mathrm{m} \mathrm{sec}^{-1}$ to $\left(9 \times 10^{-7}-5 \times 10^{-4}\right) \mathrm{m} \mathrm{sec}^{-1}$ (Domenico and Schwartz 1990), respectively, depending on the size, volume and connection of pores in the constituent sediments. The sediments of the confined aquifer between Sites C-2 and C-3 are moderately sorted fine to medium sands. The velocities calculated from the representative permeability range (mentioned above), estimated porosity $(25 \pm 5 \%)$ and hydraulic gradient $\left(\sim 1.4 \times 10^{-3}\right)$ of the Choushuichi fan delta are from $89 \mathrm{~m} \mathrm{yr}^{-1}$ to $3.6 \times 10^{-2} \mathrm{~m} \mathrm{yr}^{-1}$. All the velocities shown in Table 1 are within this range and are at least reasonable.

However, the straightforward calculation, based on the concept of bomb-tritium front, of the groundwater flow velocity for the confined aquifer under the mid-fan area shows a high value of $150-250 \mathrm{~m} \mathrm{yr}^{-1}(6 \mathrm{~km} / 40 \mathrm{yr}-10 \mathrm{~km} / 40 \mathrm{yr}),>20$ times that obtained in Table 1 for the middle and distal parts of the fan delta. The ${ }^{14} \mathrm{C}$ ages of the water samples also increase rapidly across the bombtritium front. This evidence suggests that the flow velocities of the confined aquifer drastically 
accelerated with increased pumping in recent years. In addition to the flow velocities calculated by the relative ages (Table 3 ), ages as old as 18 ka for the water samples from the distal area also imply very low natural flow velocities.

The ${ }^{14} \mathrm{C}$ ages of groundwater in the confined aquifer are evidently greater in the southwestern portion of the fan delta. It is interesting that, in the same areas, sediments are finer, land subsidence is greater and the depression cone deeper (Fig. 1) under almost the same amount of groundwater pumping.

\section{ConCLusion}

A regional aquitard was found between ca. -30 and $-60 \mathrm{~m}$ below ground surface in the central and distal parts of the Choushuichi fan delta. The long-term flow velocities calculated by the relative ${ }^{14} \mathrm{C}$ ages of the groundwater in the confined aquifer are $<10 \mathrm{~m} \mathrm{yr}^{-1}$. Average recharge rate in the proximal fan area has been $c a .5 .4 \times 10^{8} \mathrm{~m}^{3} \mathrm{yr}^{-1}$ for the past $40 \mathrm{yr}$, using the concept of "bomb-tritium front". Total recharge in the whole fan delta was estimated at $9.0 \times 10^{8} \mathrm{~m}^{3} \mathrm{yr}^{-1}$, which agrees well with previous results calculated by the water budget method in an early groundwater investigation. Recent increased pumping has drastically accelerated the flow velocities of the groundwater in the regional confined aquifer. This study demonstrates that the bomb-tritium front is good for tracing groundwater flow, at least, in alluvial-fan deltas.

\section{ACKNOWLEDGMENTS}

This research was supported by the National Science Council, Republic of China, under grant No. NSC83-0202-M002-015, Central Geological Survey, MOEA, Taipei and Taiwan Water Conservancy Bureau. Thanks are due S. J. Kong and C. Y. Chou for their technical assistance with ${ }^{14} \mathrm{C}$ measurements and C. J. Peng, B. Y. Chang, Z. L. Biq, and J. S. Huang for assisting in the field sampling. The help of S. F. Hsiao, and N. Chou for typing and drafting is appreciated. I gratefully acknowledge Dr. K. Froehlich and the editors of RADIOCARBON for their valuable comments, suggestions and patience to upgrade the manuscript.

\section{REFERENCES}

Allison, G. B. and Hughes, M. W. 1975 The use of environmental tritium to estimate recharge to a South-Australian aquifer. Journal of Hydrology 26: 245-254.

Broecker, W. and Peng, T. -H. 1982 Tracers in the Sea. Palisades, New York, Eldigio Press: 690 p.

Brown, R. M. 1961 Hydrology of tritium in the Ottawa Valley. Geochimica et Cosmochimica Acta 21: 199204.

Cheng, S. 1992 Reaction-path formulation of a simple dissolution model for radiocarbon dating groundwater. In Long, A. and Kra, R. S., eds., Proceedings of the 14th International ${ }^{14} \mathrm{C}$ Conference. Radiocarbon 34 (3): 646-653.

Daniels, D. P., Fritz, S. J. and Leap, D. I. 1991 Estimating recharge rates through unsaturated glacial till by tritium tracing. Ground Water 29(1): 26-34.

Deines, P., Langmuir, D. and Harmon, R. S. 1974 Stable carbon isotope ratios and the existence of a gas phase in the evolution of carbonate ground water. Geochimica et Cosmochimica Acta 38: 1147-1164.
Domenico, P. A. and Schwartz, F. W. 1990 Physical and Chemical Hydrogeology. New York, John Wiley \& Sons: $824 \mathrm{p}$.

Egboka, B. C. E., Cherry, J. A., Farvolden, R. N. and Frind, E. O. 1983 Migration of contaminants in groundwater at a landfill, a case study: Tritium as an indicator of dispersion and recharge. Journal of $\mathrm{Hy}$ drology 63: 51-80.

Fontes, J. Ch. and Garnier, J. M. 1979 Determination of the initial ${ }^{14} \mathrm{C}$ activity of the total dissolved carbon: $\mathrm{A}$ review of the existing models and a new approach. Water Resources Research 15: 399-413.

Geyh, M. A. and Wagner, R. H. (ms.) 1979 Guideline for groundwater sampling for isotope analyses. Unpublished laboratory notes, ${ }^{14} \mathrm{C}$ and ${ }^{3} \mathrm{H}$-Laboratory, Niedersachsische Landesamt für Bodenforschung, Hannover, Germany.

Ground Water Investigation Team (GWIT) 1957 Ground water investigation in Tachoushui alluvial plain report. Taichung, Taiwan: $156 \mathrm{p}$. 
Hackley, K. C., Liu, C. L. and Coleman, D. D. $1992{ }^{14} \mathrm{C}$ dating of groundwater containing microbial $\mathrm{CH}_{4}$. In Long, A. and Kra, R. S., eds., Proceedings of the 14th International ${ }^{14} \mathrm{C}$ Conference. Radiocarbon $34(3)$ : 686-695.

Huang, J. S. 1992 A perspective of ground-water management considering sustainable usage of water resources in Taiwan. In Proceedings of the Conference on the Investigation, Analysis and Management of Groundwater. 1-17 (in Chinese).

Ingerson, E. and Pearson, F. J., Jr. 1964 Estimation of age and rate of motion of ground-water by the ${ }^{14} \mathrm{C}$ method. In Miyake, Y. and Koyama, T., eds., Recent Research in the Field of Hydrosphere, Atmosphere, and Nuclear Geochemistry. Tokyo, Maruzen: 263-283.

Kaufman, S. and Libby, W. F. 1954 The natural distribution of tritium. Physical Review 93: 1337-1344.

Lee, B. D. and Lin, M. H. (ms.) 1992 Groundwater salinization in the land-subsidence areas of south-western Taiwan. Paper presented at Conference on Groundwater Surveying, Analysis, and Management. Taipei, Taiwan, 17-18 October: 557-568.

Mook, W. G. 1976 The dissolution-exchange model for dating groundwater with ${ }^{14} \mathrm{C}$. In Interpretation of Environmental Isotope and Hydrochemical Data in Groundwater Hydrology. Vienna, IAEA: 213-225.

1980 Carbon-14 in hydrogeological studies. In Fritz, P. and Fontes, J.-Ch., eds., Handbook of Environmental Isotope Geochemistry. New York, Elsevier Science Publishers: 49-74.

Parkhurst, D. L., Thorstenson, D. C. and Plummer, L. N. 1980 PHREEQE - A Computer Program for Geochemical Calculations. Water Resources Investigations 80-96. Reston, Virginia, U.S. Geological Survey: $210 \mathrm{p}$.

Pearson, F. J., Jr. 1965 Use of ${ }^{13} \mathrm{C} /{ }^{12} \mathrm{C}$ ratios to correct radiocarbon ages of materials initially diluted by lime- stone. In Chatters, R. M. and Olson, E. A., eds., Proceedings of the 6th International Conference on Radiocarbon and Tritium Dating. Clearinghouse for Federal Scientific and Technical Information, Washington, DC: $357-366$.

Plummer, L. N., Busby, J. F., Lee, R. W. and Hanshaw, B. B. 1990 Geochemical modeling of the Madison aquifer in parts of Montana, Wyoming and South Dakota. Water Resources Research 26: 1981-2014.

Reardon, E. J. and Fritz, P. 1978 Computer modeling of groundwater ${ }^{13} \mathrm{C}$ and ${ }^{14} \mathrm{C}$ isotope compositions. Journal of Hydrology 36: 201-224.

Robertson, W. D. and Cherry, J. A. 1989 Tritium as an indicator of recharge and dispersion in a groundwater system in central Ontario. Water Resources Research 25(6): 1097-1109.

Stuiver, M. and Polach, H. A. 1977 Discussion: Reporting of ${ }^{14} \mathrm{C}$ data. Radiocarbon 19(3): 355-363.

Taiwan Water Conservancy Bureau (TWCB) 1974 Preliminary report for the research on land subsidence problems in the Tulin-Chiai area. Taiwan Water Conservancy Reports 26(1): 47-66.

Tamers, M. A. 1967 Radiocarbon ages of groundwater in an arid zone unconfined aquifers. In Stout, G. E., ed., Isotope Techniques in the Hydrologic Cycle. AGU Monograph Series 11. Washington, DC, American Geophysical Union: 143-152.

1975 Validity of radiocarbon dates on groundwater. Geophysical Surveys 2: 217-239.

Wang, C. S. and Chen, C. S. 1959 Geological investigation on the groundwater resources in and around $\mathrm{Ta}$ choshuichi fan between Changhua and Yunglin districts. Acta Geologica Taiwanica 7: 35-42.

Wigley, T. M. L., Plummer, L. N. and Pearson, F. J., Jr., 1978 Mass transfer and carbon isotope evolution in natural water systems. Geochimica et Cosmochimica Acta 42: 1117-1139. 